\title{
Effect of fast protein liquid chromatography fractionated salivary gland extracts from different ixodid tick species on interleukin-8 binding to its cell receptors
}

\author{
Paulína Kocáková ${ }^{1}$, Monika Sláviková $^{1}$, Valéria Hajnická $^{1}$, Mirko Slovák $^{2}$, Juraj Gašperík $^{3}$, Iveta Vančová$^{1}$, \\ tNorbert Fuchsberger ${ }^{1}$ and Patricia A. Nuttall ${ }^{4}$ \\ ${ }^{1}$ Institute of Virology, Slovak Academy of Sciences, Dúbravská cesta 9, 84245 Bratislava, Slovakia; \\ ${ }^{2}$ Institute of Zoology, Slovak Academy of Sciences, Dúbravská cesta 9, 84306 Bratislava, Slovakia; \\ ${ }^{3}$ Institute of Molecular Biology, Slovak Academy of Sciences, Dúbravská cesta 21, 84251 Bratislava, Slovakia; \\ ${ }^{4} \mathrm{CEH}$ Institute of Virology and Environmental Microbiology, Mansfield Road, Oxford OX1 3SR, UK
}

Key words: Dermacentor reticulatus, Rhipicephalus appendiculatus, Amblyomma variegatum, interleukin-8, tick saliva, chemokine inhibitors

\begin{abstract}
Interleukin-8 plays a critical role in inflammatory processes. Hence generation of molecules with anti-IL-8 activity is likely to be important for successful feeding and for survival of the ticks. Anti-IL- 8 activity was studied in saliva of three ixodid tick species - Dermacentor reticulatus (Fabricius, 1794), Rhipicephalus appendiculatus Neumann, 1901, and Amblyomma variegatum (Fabricius, 1794). The greatest activity was shown in saliva prepared from $D$. reticulatus. The activity was attributed to tick salivary gland molecules that bind to IL-8, preventing binding of the chemokine to its specific receptor, rather than to occupation of the IL-8 cell receptor by the tick molecules. The distribution of anti-IL-8 activity in fast protein liquid chromatography (FPLC) fractions of salivary gland extracts (SGE) derived from adult female D. reticulatus, R. appendiculatus and A. variegatum was compared directly by both ELISA and receptor-binding inhibition assays. The correspondence in results with fractions of SGE from ELISA is consistent with detection of tick molecules that inhibit IL-8 binding to its receptor. As IL-8 is an important chemoattractant and activator of neutrophils, the presence of an anti-IL- 8 activity in tick saliva indicates that neutrophils play an important role in the host response to parasitism by ticks.
\end{abstract}

Ticks are obligate ectoparasites with remarkable morphological and physiological adaptations to bloodfeeding (Sonenshine 1991). Because of the long duration of attachment of ixodid ticks to their hosts, they provoke host inflammatory and immune responses. For successful feeding, ticks have developed different mechanisms to counter the host immune reactions including immunomodulative interactions with their host mediated by tick saliva (Ramachandra and Wikel 1992, Wang et al. 1998, Paesen et al. 1999, Valenzuela et al. 2000). In addition, tick saliva is responsible for promoting transmission of tick-borne pathogens (Jones et al. 1987, Labuda et al. 1993, Nuttall 1998), and its beneficial effect on virus growth has been confirmed in vitro (Hajnická et al. 1998, Kocáková et al. 1999).

Tick saliva has been shown to influence many immunological mechanisms, including the cytokine network (Wikel 1996a). Although inhibition of production of proinflammatory cytokines, such as interleukin-1, tumour necrosis factor alpha and interferon gamma, described previously (Fuchsberger et al. 1995), may help to decrease some aggressive host immune mechanisms, the binding of chemokines also provides an excellent strategy for modulating host cellular inflam- matory and immune responses (Hajnická et al. 2001). Chemokines are a subfamily of cytokines comprising mostly small secreted proteins that function in leukocyte recruitment, trafficking and recirculation. They play a critical role in inflammation and combating infectious diseases (Baggiolini 1998, Lalani et al. 2000). Instead of developing complicated mechanisms to paralyse particular immune functions of immunocompetent cells, a simpler strategy is to bind the corresponding chemokine and prevent it binding to its receptor(s). The first evidence of tick saliva interaction with chemokines was the demonstration of anti-interleukin-8 (IL-8) activity with salivary gland extracts (SGE) (Hajnická et al. 2001). IL-8 is an important chemoattractant and activator of neutrophils (Baggiolini et al. 1994). Granulocytes (neutrophils, eosinophils, and basophils) comprise the acquired and innate cellular defence against microorganisms and parasites. Under normal conditions, neutrophils constitute 40 to $70 \%$ of the circulating leukocytes, whereas eosinophils and basophils collectively represent no more than 5\% (Roos et al. 1997). Neutrophils are capable of phagocytosis of particulate material and use the contents of their granules for killing ingested microorganisms and for 
extracellular lysis of parasites. Hence neutrophils pose a threat to both ticks and tick-transmitted pathogens. The significance of anti-IL-8 activity detected in tick SGE was demonstrated by the ability of SGE to inhibit IL-8 induced chemotaxis of human blood granulocytes (Hajnická et al. 2001). Because of the obvious importance of these observations, we undertook further studies to clarify the nature of the anti-IL- 8 activity.

Here we analyse tick saliva and compare the inhibitory profile of IL-8 binding to its specific receptor for selected FPLC fractions of SGE derived from three different tick species. The results provide strong evidence of IL- 8 binding molecules in the saliva of ixodid ticks that prevent IL-8 binding to its neutrophil receptors.

\section{MATERIALS AND METHODS}

\section{Ticks and preparation of SGE}

Dermacentor reticulatus (Fabricius, 1794) ticks were collected by flagging the vegetation in selected localities of western Slovakia known to be free of tick-borne encephalitis virus. Rhipicephalus appendiculatus Neumann, 1901 and Amblyomma variegatum (Fabricius, 1794) ticks were obtained from laboratory colonies (Jones et al. 1988). Adult ticks were allowed to feed either on ICR mice ( $D$. reticulatus), guineapigs ( $R$. appendiculatus) or on rabbits (A. variegatum). Previous studies have shown that immunomodulatory activity of SGE is typically upregulated during feeding (Ramachandra and Wikel 1992, Kubeš et al. 1994, Paesen et al. 1999). As adult female $D$. reticulatus and $R$. appendiculatus take on average 9 days to complete engorgement, they were collected at day 5-6 of feeding; adult female A. variegatum take 12-14 days to complete engorgement and were collected at day 10 of feeding (Jones et al. 1988, Slovák et al. 2002). SGE was prepared by modifying the method of Slovák et al. (2000). The feeding ticks were gently removed from the laboratory animals and their salivary glands dissected out in ice cold sterilized $0.15 \mathrm{M} \mathrm{NaCl}(0.9 \%)$, washed three times with the same solution and pooled in Eppendorf tubes containing $10 \mu 1$ $0.15 \mathrm{M} \mathrm{NaCl}$ in deionized water. Salivary glands were then homogenized and centrifuged at $10,000 \times \mathrm{g}$ for $30 \mathrm{~min}$ at $4^{\circ} \mathrm{C}$. Protein concentration of SGE supernates was determined using the Bradford method (1976). Supernatant fluids were dried using a Speed-Vac, stored at $4^{\circ} \mathrm{C}$ and rehydrated prior to use.

\section{SGE fractionation by fast protein liquid chromatography} (FPLC)

SGE prepared from $D$. reticulatus $(3.3 \mathrm{mg}$ proteins from 66 ticks), $R$. appendiculatus (1.97 $\mathrm{mg}$ proteins from 121 ticks) and A. variegatum (3.06 mg proteins from 28 ticks) female ticks was separated by FPLC under native conditions at $5^{\circ} \mathrm{C}$ using a Superose 12 HR10/30 column (Pharmacia, Sweden) with an equilibrium buffer of $0.02 \mathrm{M}$ Tris- $\mathrm{HCl}, 0.15 \mathrm{M} \mathrm{NaCl}$, $\mathrm{pH} 7.5$, flow rate of $0.4 \mathrm{ml} / \mathrm{min}$ and one fraction collected per $\min$.

\section{Collection of tick saliva}

Feeding ticks removed from their host were rinsed in water to remove any superficial blood contamination and immobilised by dorsal attachment to double-sided tape. To induce secretion, $2 \mathrm{mM}$ 3-hydroxytyramine hydrochloride (dopamine; Sigma) was inoculated into the coxal plate of the second pair of legs using specially prepared glass microcapillary tubes. The mouthparts (hypostome and chelicerae) were then inserted into a capillary tube (Kwik-Fil Glass Capillaries, W-P Instruments, USA) with internal hole diameter appropriate to their size. Secretion usually takes place within a minute after inoculation of dopamine; extra stimulation was applied by weak pressure on the ventral side of the tick's opisthosoma. Secretion ceases within about 30 minutes, after which the tick may withdraw some or all of the fluid. Saliva was collected in Eppendorf tubes containing 10 $\mu 10.15 \mathrm{M} \mathrm{NaCl}$ and then handled according to procedures described for SGE preparation, including protein measurement. Saliva samples prepared from 10 days-fed Amblyomma variegatum (6 female ticks), 5 days-fed Dermacentor reticulatus (12 female ticks) and 6 days-fed Rhipicephalus appendiculatus ( 8 female ticks) were rehydrated to the final concentration $5 \mu \mathrm{g} / 5 \mu \mathrm{l} /$ well prior to examination by $\mathrm{IL}-8$ ELISA.

\section{Isolation of cells from peripheral human blood}

Granulocytes were isolated from 10 to $15 \mathrm{ml}$ of fresh human blood collected into heparin $\left(5 \times 10^{3} \mathrm{U} / \mathrm{ml}\right.$; Léčiva Praha) and diluted $1: 2$ in $0.15 \mathrm{M} \mathrm{NaCl}$. Cell suspensions were resuspended in $24 \mathrm{ml}$ of deionized water for $30 \mathrm{sec}$ to lyse erythrocytes. Following lysis, $8 \mathrm{ml}$ of $0.6 \mathrm{M} \mathrm{NaCl}$ (3.6\%) were added to stop the hypotonic shock treatment. Cells were washed with $0.15 \mathrm{M} \mathrm{NaCl}$ and resuspended in RPMI medium supplemented with $10 \%$ of foetal bovine serum. Cell number was determined using Türk's solution and diluted to a final concentration of $4 \times 10^{6}$ cells $/ \mathrm{ml}$. For the receptor-binding assay, $50 \mu 1$ of cell suspension per sample were used.

\section{Interleukin-8 detection by ELISA}

The IL-8 ELISA R\&D Systems kit was used. For each assay, 100 pg of recombinant human IL-8 (R\&D Systems, Abingdon, UK) in Leibovitz L-15 medium supplemented with $5 \%$ bovine calf serum were mixed with tick saliva or FPLC fractions $(200 \mathrm{pg} / 205 \mu \mathrm{l}$ mixture $)$ in Eppendorf tubes. Each mixture was incubated $2 \mathrm{~h}$ at room temperature with gentle shaking and then applied to the ELISA plates $(100 \mu 1 /$ well). Obtained results represent an average of 2 parallels from two measurements.

\section{Receptor-binding inhibition assay}

a) Testing unfractionated SGE. SGE was prepared from D. reticulatus females that had been feeding for 5 days. SGE was diluted in phosphate buffered saline (PBS) to a final concentration $5 \mu \mathrm{g} / 50 \mu \mathrm{l}$. Solutions of SGE were mixed with $1.2 \mu 1\left[{ }^{125} \mathrm{I}\right]$-labelled IL-8 (NEN Life Science Products, USA). In addition, $1.2 \mu 1\left[{ }^{125} \mathrm{I}\right] \mathrm{IL}-8$ were diluted with $50 \mu \mathrm{l}$ of PBS. Mixtures of $\left[{ }^{125} \mathrm{I}\right] \mathrm{IL}-8+$ SGE and $\left[{ }^{125} \mathrm{I}\right]$ IL-8 + PBS were incubated for $1 \mathrm{~h}$ at room temperature. Cells prepared as described above were treated either with these mixtures or $\left[{ }^{125} \mathrm{I}\right]$ IL-8 was added to the cells after pretreatment of cells with SGE solution $(5 \mu \mathrm{g})$ or IL-8 $(50 \mathrm{ng})$. After a further $1 \mathrm{~h}$ incubation at room temperature, all samples were washed 3 times with PBS. Pellets of cells were resuspended in $50 \mu 1$ PBS and the radioactivity was measured using a gammacounter. All treatments were undertaken in triplicate. 
b) Testing FPLC fractions of SGE. SGE derived from $D$. reticulatus, $R$. appendiculatus and $A$. variegatum ticks was fractionated by FPLC. For receptor-binding inhibition assays, $10 \mu \mathrm{l}$ of selected fractions were diluted in $40 \mu \mathrm{l}$ of PBS and mixed with $1.2 \mu 1$ of $\left[{ }^{125} \mathrm{I}\right] \mathrm{IL}-8$. The method then followed the procedure described above for unfractionated SGE.

\section{RESULTS}

\section{DETECTION OF ANTI-IL-8 ACTIVITY IN TICK SALIVA}

Saliva collected from partially fed adult female $D$. reticulatus, $R$. appendiculatus and $A$. variegatum was incubated with IL-8 and then assayed by specific ELISA. Saliva from all three species reduced the measurable level of IL-8 compared with the control, $D$. reticulatus showing the greatest effect (Fig. 1). These results confirmed our previous studies using SGE, and provide a further indication that $D$. reticulatus has particularly potent anti-IL-8 activity compared with other species examined (Hajnická et al. 2001). Because of the difficulties in obtaining sufficient quantities of tick saliva for FPLC fractionation, we used SGE in experiments to investigate receptor binding.

\section{SGE-MEDIATED INHIBITION OF $\left[{ }^{125}\right.$ I] IL-8 BINDING TO} ITS RECEPTOR

We examined whether the inhibition of binding of the chemokine to its cell receptor is based on a) binding of the saliva component to the chemokine, or b) occupation of the cell receptor by the tick saliva component. The results are shown in Fig. 2.

a) Treatment of $\left[{ }^{125} \mathrm{I}\right]$ IL-8 with Dermacentor reticulatus SGE before incubation with cells. Binding of $\left[{ }^{125} \mathrm{I}\right]$ IL-8 to its cell receptors (Fig. 2, A), and the reduced level of binding of $\left[{ }^{125} \mathrm{I}\right] \mathrm{IL}-8$ to its cell receptors after pretreatment of cells with unlabelled IL-8 (Fig. 2, B), demonstrate good specificity of binding. By comparison, almost complete inhibition of binding was observed for $\left[{ }^{125} \mathrm{I}\right]$ IL-8 mixed with SGE (Fig. 2, C).

b) Treatment of cells with Dermacentor reticulatus SGE before incubation with $\left[{ }^{125} \mathrm{I}\right]$ IL-8. Fig. 2, $\mathrm{D}$ shows relatively poor inhibition of binding of $\left[{ }^{125} \mathrm{I}\right]$ IL-8 when cells were pretreated with SGE. When compared with $a$ ), the results indicate that the inhibition is caused by binding of SGE to $\left[{ }^{125} \mathrm{I}\right]$ IL- 8 rather then binding of SGE to cell receptors. The slight inhibition following pretreatment of cells is probably caused by the difficulty of efficient washing of SGE from the cell surface.

Collectively, the results shown in Fig. 2 indicate that a component(s) of SGE is targeting the chemokine rather than the chemokine receptor.

COMPARISON OF ANTI-IL-8 ACTIVITY IN FPLC FRACTIONS OF SGE BY RECEPTOR-BINDING INHIBITION ASSAY AND ELISA

Having confirmed that tick anti-IL-8 activity is directed against the chemokine, we then determined the effect of FPLC fractions of SGE on $\left[{ }^{125} \mathrm{I}\right]$ IL-8 binding to the cell receptors.

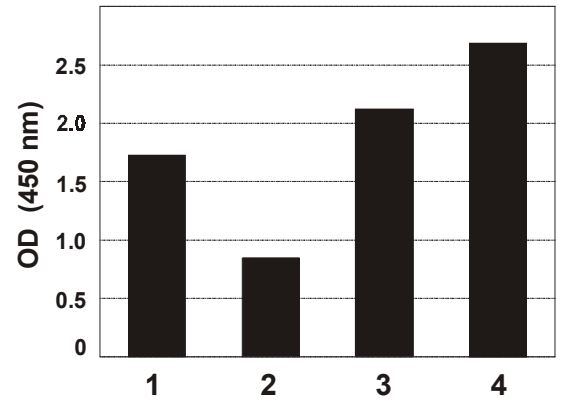

Fig. 1. Anti-IL-8 activity of tick saliva from different tick species. Detection by ELISA of 100 pg IL-8 after $2 \mathrm{~h}$ incubation with $5 \mu \mathrm{g}$ saliva collected from adult female: 1 Rhipicephalus appendiculatus; 2 -Dermacentor reticulatus; 3 - Amblyomma variegatum; 4 - 100 pg IL-8 (control). A reduction in optical density (OD) relative to the control indicates a decrease in the amount of IL-8 detected.

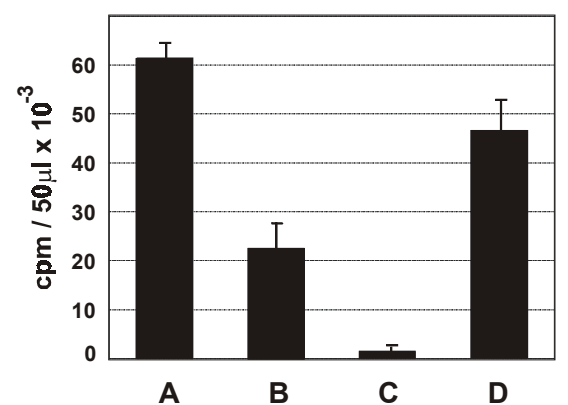

Fig. 2. Dermacentor reticulatus SGE-induced inhibition of $\left[{ }^{125} \mathrm{I}\right]$ IL-8 binding to specific receptors on human granulocytes. A - $\left[{ }^{125} \mathrm{I}\right] \mathrm{IL}-8$ binding to control cells treated with PBS; $\mathrm{B}$ - reduced binding of $\left.{ }^{[25} \mathrm{I}\right]$ IL- 8 in the presence of unlabelled IL-8 showing the specificity of binding; C pretreatment of $\left[{ }^{125} \mathrm{I}\right] \mathrm{IL}-8$ with $5 \mu \mathrm{g}$ SGE; D - pretreatment of cells with $5 \mu \mathrm{g}$ SGE.

First, fractionated SGE of adult female $D$. reticulatus, $R$. appendiculatus and $A$. variegatum was tested by IL-8 specific ELISA. To obtain approximately the same effects against $100 \mathrm{pg}$ of IL-8, $1 \mu \mathrm{l}$ of $D$. reticulatus (Fig. 3), $10 \mu \mathrm{l}$ of $R$. appendiculatus (Fig. 4) or $6 \mu \mathrm{l}$ of $A$. variegatum (Fig. 5) fractions per well were used.

Fractions selected on the basis of the ELISA results were then incubated with $\left[{ }^{125} \mathrm{I}\right] \mathrm{IL}-8$ and tested using the receptor-binding inhibition assay. The amount of bound $\left[{ }^{125} \mathrm{I}\right] \mathrm{IL}-8$ was compared with the control (cells treated with $\left[{ }^{125} \mathrm{I}\right]$ IL-8 + PBS). Ranges of fractions showing the highest $\%$ inhibition of $\left[{ }^{125} \mathrm{I}\right]$ IL-8 binding corresponded with the ELISA activity profiles. This correspondence was even reflected in the two peaks of activity demonstrated by SGE fractions of $A$. variegatum (Fig. 5). The similarities in activity profiles detected by the two methods indicate that tick salivary gland molecules prevent detection of IL- 8 by specific antibody (ELISA results) and inhibit binding of $\left[{ }^{125} \mathrm{I}\right]$ IL-8 to its specific receptor (receptor-binding assay results). Both observations are consistent with the presence of tick IL- 8 binding molecules. 


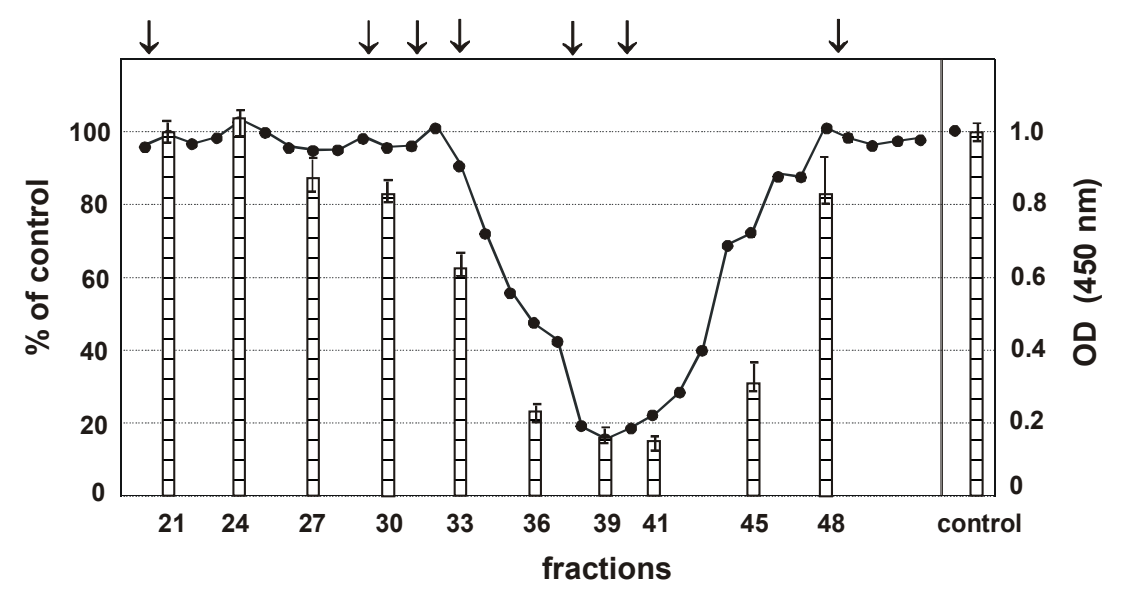

Fig. 3. Anti-IL-8 activity in FPLC fractions of SGE derived from Dermacentor reticulatus ticks demonstrated by: $\longrightarrow-$ specific ELISA. A reduction in optical density relative to the control indicates a decrease in the amount of IL-8 detected. س - receptorbinding inhibition assay. $\left[{ }^{125} \mathrm{I}\right] \mathrm{IL}-8$ was incubated with $10 \mu \mathrm{FPLC}$ fractions before treatment of the human granulocytes. Mean values $\pm \operatorname{SE}(n=3)$. Arrows indicate the elution positions of relative molecular weight standards (from left to the right): blue dextran $(2000 \mathrm{kDa})$, aldolase $(158 \mathrm{kDa})$, BSA (68 kDa), ovalbumin (45 kDa), chymotrypsinogen A (25 kDa), RNase A (13.7 $\mathrm{kDa})$ and bacitracin $(1.45 \mathrm{kDa})$.

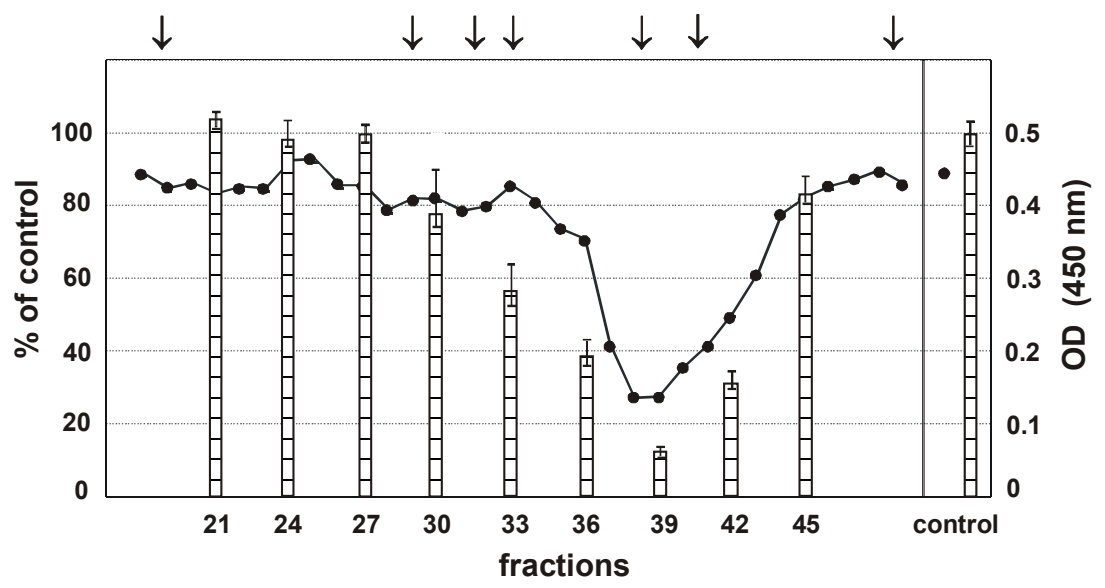

Fig. 4. Anti-IL-8 activity in FPLC fractions of SGE derived from Rhipicephalus appendiculatus ticks demonstrated by: $\longrightarrow-$ specific ELISA. A reduction in optical density relative to the control indicates a decrease in the amount of IL-8 detected. receptor-binding inhibition assay. $\left[{ }^{125} \mathrm{I}\right] \mathrm{IL}-8$ was incubated with $10 \mu \mathrm{FPLC}$ fractions before treatment of the human granulocytes. Mean values $\pm \operatorname{SE}(n=3)$. Arrows as in Fig. 3 .

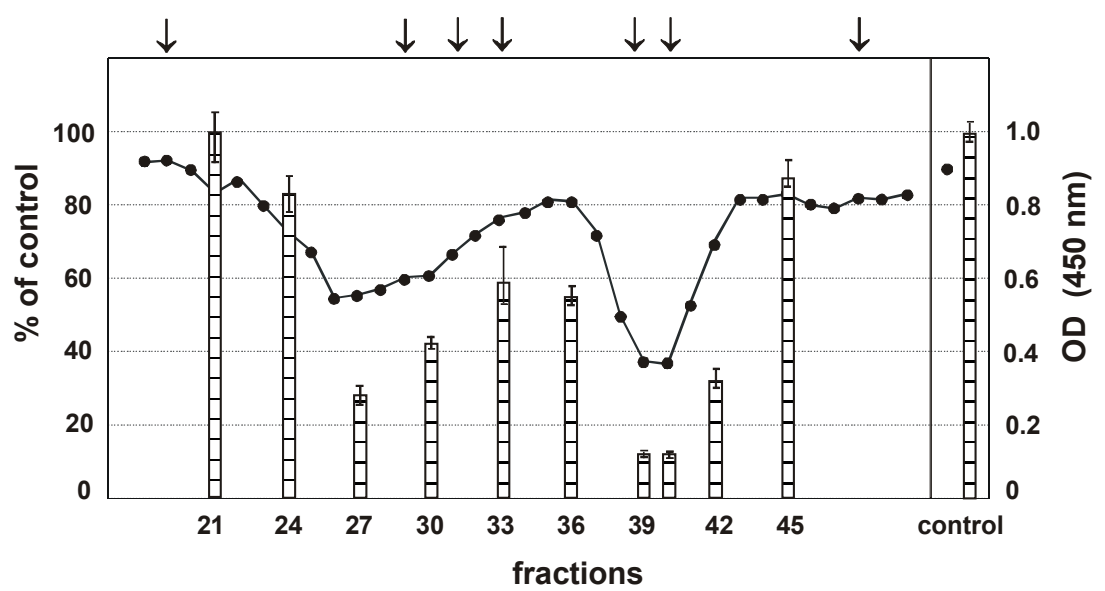

Fig. 5. Anti-IL-8 activity in FPLC fractions of SGE derived from Amblyomma variegatum ticks demonstrated by: $\longrightarrow$ specific ELISA. A reduction in optical density relative to the control indicates a decrease in the amount of IL-8 detected. $\square-$ receptorbinding inhibition assay. $\left[{ }^{125} \mathrm{I}\right] \mathrm{IL}-8$ was incubated with $10 \mu \mathrm{FPLC}$ fractions before treatment of the human granulocytes. Mean values $\pm \operatorname{SE}(\mathrm{n}=3)$. Arrows as in Fig. 3 . 


\section{DISCUSSION}

Two basic strategies exist to manipulate the cytokine network. One possibility is to inhibit the production of cytokines (Fuchsberger et al. 1995) whereas the alternative is to inhibit their action (Gillespie et al. 2001). The latter may occur either by occupying the receptor or by direct binding of the cytokine (for example, the IL-2 binding protein of Ixodes scapularis, Gillespie et al. 2001). Results presented here confirm our preliminary finding that tick salivary glands contain substances capable of interacting with the IL-8 molecule and consequently inhibiting its action. We also show the first evidence of anti-IL- 8 activity in tick saliva. Hence we propose that an IL-8 binding molecule(s) is produced in tick salivary glands and secreted in tick saliva. Presumably, the role of this chemokine binder is to control the migration of neutrophils to the tick feeding site and subsequent neutrophil activation and amplifi-cation of the host inflammatory/immune response. How-ever, published data do not give a clear indication of an IL- 8 binder's function.

The role and response of neutrophils to tick feeding depend on the host species and whether the host is naive (no previous exposure to ticks), tolerant (previously exposed to ticks but showing little response) or immune (previous exposure having elicited an immune-mediated rejection response) (Wikel 1996b). Resistant animals show cutaneous basophil hypersensitivity, a delayedtype hypersensitivity reaction characteristic of a Th1type response (Allen 1973, 1989, Brossard and Fivaz 1982). Neutrophils do not migrate in response to delayed-type hypersensitivity induced in skin (Roos et al. 1997). In marked contrast to the response of immune hosts, changes recorded during an initial infestation of naïve animals are often slight (Trager 1939, Allen 1973). However, following infestation of naïve laboratory mice with Ixodes ricinus nymphs, a 10- to 100-fold increase in the number of leukocytes (predominantly neutrophils) was observed to emigrate from skin explants where ticks were feeding compared with uninfested skin sites (Labuda et al. 1996). Neutrophil accumulation at tick attachment sites was reported during primary infestation of Rhipicephalus sanguineus on dogs (Tatchell and Moorhouse 1970) and Dermacentor variabilis on albino rats (Berenberg et al. 1972). Cleavage products of the complement component C5 induced chemotactic attraction of neutrophils to the tick feeding site (Berenberg et al. 1972). The cleavage products were attributed to the direct action of tick salivary components on serum. However, this study was undertaken before the discovery of IL- 8 and its important role as a neutrophil chemoattractant in addition to C5a and PAF (platelet aggregating factor) produced by the host, and fMLP (formyl-methionyl-leucyl-phenylalanine) released by infecting microorganisms. Indeed, IL-8 seems to form the basis of a low-level turnover of neutrophils in the skin. This chemoattraction without activation may provide tissue protection by renewal of the short-lived neutrophil population (Roos et al. 1997). Thus a tick anti-IL-8 activity may be of particular importance in primary infestation of naïve animals.

An added complication in assessing the role of IL-8 binding molecules in tick blood-feeding is that IL-8 is only one of many inflammatory mediators. Indeed, it seems likely that ticks produce an armoury of antiinflammatory molecules. All three ixodid species shown here to produce IL- 8 binders use a similar strategy to control host vasoactive amines. Both Rhipicephalus appendiculatus and Amblyomma variegatum produce histamine-binding proteins (Paesen et al. 1999 and unpublished data), and Dermacentor reticulatus produces a protein that binds both histamine and serotonin (Sangamnatdej et al. 2002). Histamine is a key mediator of inflammation produced by mast cells and basophils; serotonin plays a similar role but is particularly important in rodents. The differences between the species suggest molecular adaptation of saliva molecules to the hosts on which the ticks feed, as $R$. appendiculatus, $A$. variegatum and adult $D$. reticulatus feed on cattle whereas immature D. reticulatus feed on rodents. By extrapolation, identifying the pharmacological constituents of tick saliva should reveal what host components are important at the tick-host interface. Thus discovery of IL-8 binding molecules is a strong indication that neutrophils play an important part in the host response to tick blood-feeding although, as discussed above, the exact role is unclear at present. Neutrophils also have the potential to control invasion and infection by ticktransmitted pathogens raising the possibility that tick deactivators of IL-8 also promote pathogen transmission (Hajnická et al. 2001).

Acknowledgements. We appreciate the skilled technical assis-tance of Mrs Meriová, Grancová and Holá. This research was supported by VEGA grant 2/1031/21 and Evolutec Ltd.

\section{REFERENCES}

ALLEN J.R. 1973: Tick resistance: basophils in skin reactions of resistant guinea pigs. Int. J. Parasitol. 3: 195-200.

ALLEN J.R. 1989: Immunology of interactions between ticks and laboratory animals. Exp. Appl. Acarol. 7: 5-13.
BAGGIOLINI M. 1998: Chemokines and leukocyte traffic. Nature 392: 565-568.

BAGGIOLINI M., DEWALD B., MOSER B. 1994: Interleukin- 8 and related chemotactic cytokines - CXC and CC chemokines. Adv. Immunol. 55: 97-179. 
BERENBERG J.L., WARD P.A., SONENSHINE D.E. 1972: Tick-bite injury: mediation by a complement-derived chemotactic factor. J. Immunol. 109: 451-456.

BRADFORD M.M. 1976: A rapid and sensitive method for the quantitation of microgram quantities of protein utilizing the principle of protein-dye binding. Anal. Biochem. 72: 248-254.

BROSSARD M., FIVAZ V. 1982: Ixodes ricinus L.: mast cells, basophils and eosinophils in the sequence of cellular events in the skin of infested or re-infested rabbits. Parasitology 85: 583-592.

FUCHSBERGER N., KITA M., HAJNICKÁ V., IMANISHI J., LABUDA M., NUTTALL P.A. 1995: Ixodid tick salivary gland extracts inhibit production of lipopolysaccharide-induced mRNA of several different human cytokines. Exp. Appl. Acarol. 19: 671-676.

GILLESPIE R.D., DOLAN M.C., PIESMAN J., TITUS R.G. 2001: Identification of an IL-2 binding protein in the saliva of the Lyme disease vector tick, Ixodes scapularis. J. Immunol. 166: 4319-4327.

HAJNICKÁ V., FUCHSBERGER N., SLOVÁK M., KOCÁKOVÁ P., LABUDA M., NUTTALL P.A. 1998: Tick salivary glands extracts promote virus growth in vitro. Parasitology 116: 533-538.

HAJNICKÁ V., KOCÁKOVÁ P., SLÁVIKOVÁ M., SLOVÁK M., GAŠPERÍK J., FUCHSBERGER N., NUTTALL P.A. 2001: Anti-interleukin- 8 activity of tick salivary gland extracts. Parasite Immunol. 23: 483-489.

JONES L.D., DAVIES C.R., STEELE G.M., NUTTALL P.A. 1987: A novel mode of arbovirus transmission involving a nonviraemic host. Science 237: 775-777.

JONES L.D., DAVIES C.R., STEELE G.M., NUTTALL P.A. 1988: The rearing and maintenance of ixodid and argasid ticks in the laboratory. Anim. Technol. 39: 99-106.

KOCÁKOVÁ P., HAJNICKÁ V., SLOVÁK M., NUTTALL P.A., FUCHSBERGER N. 1999: Promotion of vesicular stomatitis virus nucleocapsid protein production by arthropod saliva. Acta Virol. 43: 251-254.

KUBEŠ M., FUCHSBERGER N., LABUDA M., ŽUFFOVÁ E., NUTTALL P.A. 1994: Salivary gland extracts of partially fed Dermacentor reticulatus ticks decrease natural killer cell activity in vitro. Immunology $82: 113$ 116.

LABUDA M., AUSTYN J., ZUFFOVA E., KOZUCH O., FUCHSBERGER N., LYSY J., NUTTALL P.A. 1996: Importance of localized skin infection in tick-borne encephalitis virus transmission. Virology 219: 357-366.

LABUDA M., JONES L.D., WILLIAMS T., NUTTALL P.A. 1993: Enhancement of tick-borne encephalitis virus transmission by tick salivary gland extracts. Med. Vet. Entomol. 7: 193-196.
LALANI A.S., BARRETT J.W., McFADDEN G. 2000: Modulating chemokines: more lessons from viruses. Immunol. Today 21: 100-106.

NUTTALL P.A. 1998: Displaced tick-parasite interactions at the host interface. Parasitology 116: S65-S72.

PAESEN G.C., ADAMS P.L., HARLOS K., NUTTALL P.A., STUART D.I. 1999: Tick histamine-binding proteins: isolation, cloning, and three-dimensional structure. Mol. Cell 3: 661-671.

RAMACHANDRA R.N., WIKEL S.K. 1992: Modulation of host-immune responses to ticks (Acari: Ixodidae): effect of salivary gland extracts on host macrophages and lymphocyte cytokine production. J. Med. Entomol. 29: 818-826.

ROOS D., KUIJPERS T.W., KNOL E.F. 1997: Neutrophils, eosinophils, and basophils in the skin immune system. In: J.D. Bos (Ed.), Skin Immune Systems (SIS): Cutaneous Immunology and Clinical Immunodermatology. CRC Press, Boca Raton, New York, pp. 185-203.

SANGAMNATDEJ S., PAESEN G.C., SLOVÁK M., NUTTALL P.A. 2002: A high affinity serotonin- and histamine-binding lipocalin from tick saliva. Insect Mol. Biol. 11: 79-86.

SLOVÁK M., HAJNICKÁ V., LABUDA M., FUCHSBERGER N. 2000: Comparison of the protein profiles of salivary gland extracts derived from three species of unfed and partially fed ixodid ticks analysed by SDS-PAGE. Folia Parasitol. 47: 67-71.

SLOVÁK M., LABUDA M., MARLEY S.E. 2002: Mass laboratory rearing of Dermacentor reticulatus ticks (Acarina: Ixodidae). Biologia (Bratislava) 57: 261-266.

SONENSHINE D.E. 1991: Biology of Ticks. Vol. 1. Oxford University Press, Oxford, $449 \mathrm{pp}$.

TATCHELL R.J., MOORHOUSE D.E. 1970: Neutrophils: their role in the formation of a tick lesion. Science 167 : 1002-1003.

TRAGER W. 1939: Acquired immunity to ticks. J. Parasitol. 25: 57-81.

VALENZUELA J.G., CHARLAB R., MATHER T.N., RIBEIRO J.M.C. 2000: Purification, cloning, and expression of a novel salivary anticomplement protein from the tick, Ixodes scapularis. J. Biol. Chem. 275: 18717-18723.

WANG H., PAESEN G.C., NUTTALL P.A., BARBOUR A.G. 1998: Male ticks help their mates to feed. Nature 391: 753-754.

WIKEL S.K. 1996a: Tick modulation of host cytokines. Exp. Parasitol. 84: 304-309.

WIKEL S.K. 1996b: Immunology of the skin. In: S.K. Wikel (Ed.), The Immunology of Host-Ectoparasitic Arthropod Relationships. CAB International, Wallingford, UK, pp. 1-29.

Accepted 10 September 2002 